\title{
JUSTICE VALUES FOR PROVISION OF COMPENSATION IN LAND PROCUREMENT FOR PUBLIC INTEREST
}

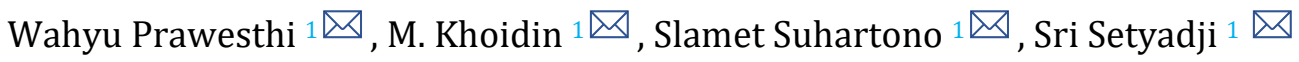 \\ ${ }^{1}$ Faculty of Law, Universitas 17 Agustus 1945 Surabaya, Indonesia
}

Received 9 November 2021

Accepted 19 December 2021

Published 31 January 2022

\section{CorrespondingAuthor}

Wahyu Prawesthi,

wahyuprawesthi20@gmail.com

DOI

10.29121/granthaalayah.v10.i1.2022 .4472

Funding: This research received no specific grant from any funding agency in the public, commercial, or not-for-profit sectors.

Copyright: (C) 2022 The Author(s). This is an open access article distributed under the terms of the Creative Commons Attribution License, which permits unrestricted use, distribution, and reproduction in any medium, provided the original author and source are credited.

\section{ABSTRACT}

Motivation/Background: The legal problems found in providing compensation in land acquisition for the public interest are vague norms in the interests of justice and feasibility. The legislation on land acquisition has not explained the provision of compensation fairly and adequately.

Method: This research uses normative legal analysis.

Results: This includes that the perspective of fairness in compensation for land acquisition is essentially still characterized by pragmatic development programs and conditions for compensation that the government has determined.

Conclusions: This shows that the provision of compensation must refer to the theory of justice, the idea of practicality and the theory of legal certainty to realize the nature of a prosperous legal state based on Indonesian Socialism and Pancasila.

Keywords: Justice, Compensation, Land Acquisition

\section{INTRODUCTION}

Proper land use can provide benefits, one of which is in the tourism industry Riyadi et al. (2019) and impact on economic stability Warjiyati et al. (2020). The land is one of the most vital sources of life for humans, one of the functions of land is used to live with the establishment of a house as a place to live Lubis (2019).Other types of land ownership include Eigendom, which means "permanent ownership," and verbonding, a tax bill on land. Therefore, Eigendom is a solid right of ownership. The term "verbonding" refers to a letter tax bill on land ownership. The type of land rights known as property rights is the most powerful. The law will no longer protect other land rights and these types of property rights if it doesn't have certificate evidence Iskandar (2019). The term "property rights" stems from the Dutch word "Eigendom," while "ownership" is used in the Dutch language Anatami (2017). According to Simanjuntak, property rights are the right to enjoy the use of an object and act freely. Against the thing with complete sovereignty, as long as it does not contradict general laws or regulations enacted by a competent body determine it. Furthermore, they do not infringe on other people's rights Simanjuntak (2015).

Assessors assessed the compensation value of the land field by field. Recommendation, in compensation discussions, as much consensus as feasible should be obtained Subekti (2016). 
The implementation of compensation in land acquisition activities is carried out based on the provisions of the applicable laws and regulations. However, in practice, despite changing several rules and regulations, there are still some obstacles faced by the government. This requires legal considerations or legal aspects that can be formulated into the background of the problem in terms of philosophical and juridical aspects, including theoretical and sociological factors.

As the organization's vision and objective, it is critical to bargain in an equal manner in order to win the common good Fensi (2018). Law Number 5 of 1960 concerning Basic Regulations on Agrarian Principles mandates that all land is for the sake of guaranteeing legal certainty over land. The Ministry of Agrarian Affairs and National Spatial Planning was noted to organize registrations throughout Indonesia to carry out this mandate. However, only \pm 48 million plots of land were recorded out of a total of \pm 130 million parcels throughout Indonesia, which can potentially cause land problems Chandra (2020). There is a lack of clarity in the meaning of the provisions of the Basic Agrarian Law Number 5 of 1960 in Article 18 as the basis for land acquisition in Indonesia regarding the feasibility of providing compensation, which in essence will guarantee the Indonesian people regarding land rights against possible revocation of rights, but bound by conditions, for example, must be accompanied by the provision of appropriate compensation. Furthermore, by referring to the provisions of Article 18 of Law Number 5 of 1960, namely Law Number 20 of 1961 concerning Revocation of Land Rights and Objects On It, regarding the nature of justice in the provisions of Article 9 of the law, it is not explained clearly, until the enactment of the provisions of Article 1 number (10) of Law Number 2 of 2012 concerning Land Procurement for Development in the Public Interest which states that "compensation is a fair and proper compensation to the entitled party". Including the ambiguity of the meaning contained in the principle of justice by providing an understanding that the focus of justice "provides a guarantee of proper compensation to the party entitled to the land acquisition process" based on the provisions of Article 2 letter (b) of Law Number 2 of 2012 concerning Land Acquisition. For Development for Public Interest.

Furthermore, it can be found that the legal problems encountered in the provision of compensation in land acquisition for the public interest are vague norms in the interests of justice and feasibility. The legislation on land acquisition has not explained the provision of compensation fairly and adequately. This includes that the values of fairness in the condition of compensation for land acquisition are essentially still characterized by pragmatic development programs and requirements for compensation that have been determined by the government Lestari (2020). This shows that the provision of compensation must refer to the theory of justice, the idea of practicality and the theory of legal certainty to realize the nature of a prosperous legal state based on Indonesian Socialism and Pancasila.

Therefore, the expropriation of land by the state for the implementation of land acquisition for development for the public interest on lands controlled by citizens or the people must not be carried out arbitrarily, especially in terms of compensation for losses that still guarantees the recognition and respect for land rights Sari (2018), Goldie (2018), Utami (2019). This includes the freedom of others and fulfilling just demands following considerations of morals, religious values, security, and public order in a democratic society and balancing the importance of benefit in such development. Therefore, the essential thing in this research is related to the values of justice in the provision of compensation.

Theoretically, justice is the essence of the law. Everyone must obtain this justice without exception. Therefore, law enforcement institutions' duty and responsibility are to create justice Yanto (2020). Satjipto Rahardjo considers that: 
"The justice referred to by Roscoe Pound can be seen in the concrete results that can be given to the community. The result should be formulating human needs as much as possible with the smallest sacrifice. Justice is an absolute element of its existence in a legal order, while about the social order, justice is defined as an ideal relationship between humans." Rahardjo (2000).

Perceptions in certain circles are also influenced by the quality of community opinion Wang and Hu (2020). It is necessary to find a clear explanation regarding the provision of compensation for land acquisition based on the values of justice. Therefore, in connection with the rationale above, this study analyses legal issues and finds out about the Values of Justice for Compensation in Land Procurement for the Public Interest.

\section{MATERIALS AND METHODS}

This research uses normative legal analysis. The goal of legal research methodology is to follow the thought path of legal research methodology, which may be classified into two categories: jurisprudential and sociological models. It will be easier to define the background of problems, problem formulation, problem objectives, research authenticity, research advantages, legal theories to be employed, conceptual framework, research methodology, systematics of writing, and literature review of the research by using legal research Arliman (2018), Efendi and Ibrahim (2018), Benuf and Azhar (2020) .

Based on the opinion of Lasswell McDougal in his book Edgar Bodenheimer, the identification of the characteristics of normative legal theory, namely Bodenheimer (1974):

1) Provide a theoretical basis for the application of legal norms that are described and prescribed by normative legal science

2) Legal norms are the focus of the study as well as the focus of normative science studies, including normative legal research methods.

3) The point of view of the establishment of legal theorists is from the point of view of internal norms (form the within) which are mandatory (the ought), but sometimes they also see external phenomena of norms in the application of law as feedback to perfect their internal point of view; and

4) Public authorities in the form of executive, legislative and judicial institutions are very important in forming, recognizing, and enforcing the law so that the law can function as a control tool in the distribution of all resources and the protection of human rights as the main target of social policy or protection of human dignity is regarded as a paramount objective of social policy.

Furthermore, it is analysed based on the doctrinal principles of legal theories, especially on the nature of justice and the concepts of national agrarian law. Based on this interpretation, it is to interpret the provisions of land acquisition, especially in the fairness of giving compensation. And it can be concluded and formulate arrangements for the provision of compensation in land acquisition based on the values of justice.

\section{RESULTS AND DISCUSSIONS}

The purpose of the law, according to Subekti, is that "the law is related to selfdevotion to the goals of the state contained in its essence is to be able to bring prosperity and be able to bring happiness to its people" Shomad and Thalib (2020). 
It served a country's goals by establishing justice and order, with the basic requirements to bring happiness and prosperity.

The meaning of justice is analysed in the theory of legal objectives. According to the description above, the meaning of justice is justice as a law with the understanding that there is no partiality, properly, not arbitrary Nasution (2011). So, justice is defined as a fair attitude or action. According to English literature, the term justice is called justice. The root word is just which means law or rights. From the meaning of justice as law, the importance of justice as lawfulness develops, namely legitimacy according to the law.

In a broader sense, another definition attached to justice is fairness, which is commensurate with the meaning of worthy or feasibility. The characteristic of fairness in the sense of excellent or appropriate can be seen from the terms used in legal science. For example, in the principle of fair play, which is one of the general principles of good governance, a fair wage is defined as a decent wage that is often found in labour law. The same thing is stated in Aristotle's concept of justice, which he calls fairness in human action, which means that justice is appropriateness in human activity Nasution (2011).

About the theory of justice, the implementation of land acquisition for the public interest is contained in the provisions of the applicable laws and regulations or those that are no longer enforced, requiring proper compensation to the holders of land rights. The compensation is the right of the holder of land rights/people, which must be carried out by the government/land acquisition organizer as the party who needs the land. This follows the natural rights of humans as individual landowners. This happens because individual property rights to land arise based on human will that occurs in changes in society as interpreted by Aristotle's opinion, which emphasizes the form of justice in balance or proportion.

Aristotle's views and opinions that:

Everything must be directed to noble ideals in the state, namely goodness and goodness that must be seen through justice and truth. The emphasis on balance or proportion in this theory of justice can be seen that the equality of rights must be the same among the same people. On the one hand, it is indeed said that justice also means unequal rights. So, the theory of justice is based on the principle of equality Nasution (2011).

According to the modern version, the theory is formulated with the expression that justice is carried out if the same things are treated equally, and unequal things are treated unequally. According to Aristotle, it is also regarded as fair if everyone receives their right proportionally, implying that distributive justice is concerned with determining ownership and a fair distribution of rights in public interactions with the state. In the sense that the state should provide to its citizens to determine rights and distribute those rights fairly.

The rights granted can be in the form of undivided goods, such as mutual benefit, for example, protection, public facilities, both administrative and physical and various other rights, which members of the community can enjoy without disturbing the rights of others. In addition, divided goods are rights or objects that can be determined and given to meet individual needs for citizens and their families, as long as the state can provide everything that its citizens need pretty or fairly. In other words, where there is distributive justice, the situation will approach the socalled state of achieving social justice for the community Ismail (1993).

Justice as equality is marked by the principles of rationality, freedom, and equality. In this case, principles that prioritize rights over the direction of benefits 
are needed. It is in this connection that John Rawls put forward two principles of justice, as follows:

The first principle holds that each person is entitled to the most extensive system of basic liberties compatible with a similar approach for everyone else. the second principle holds that social and economic inequalities are just only in so far as they work to the advantage of the least advantaged people in society Rawls (1971).

According to this viewpoint, the law, as one of the fundamental elements of society, should be based on two principles: first, the principle of equal rights (the greatest equal principle), which states that everyone should have equal access to wealth, income, food, protection, authority, power, dignity, rights, and freedom. Second, the principle of difference (the different principle) and equality of opportunity (the principle of fair equality of opportunity). The focus of distinction (the other direction) is expected to provide the most significant benefit or benefit for the least fortunate. Meanwhile, the principle of fair equality of opportunity is intended to provide equal opportunities for everyone (including those who are least convenient) to achieve the prospect of prosperity, income, and authority Tanya et al. (2010) .

John Rawls gives instructions on how to implement each of these ideas. The principle of equal rights (the greatest equal principle) should take precedence above equality of opportunity and diversity (the different directions and the principle of fair equality of opportunity). In the meantime, the fair equality of opportunity principle must take precedence over other principles Tanya et al. (2010). Suppose we pay attention to several cases regarding procurement, especially regarding compensation which tends to harm land rights holders. Juridical, the land acquisition law regulates what is meant by compensation. First, the compensated losses are only physical losses such as land, space above ground and underground buildings, and plants, objects related to land as stated in Article 33 of Law Number 2 of 2012. Meanwhile, non-physical losses are other losses that can be assessed, namely non-physical losses that can be equated with the value of money, such as losses due to loss of business or work, costs of moving places, and costs of changing professions the value of the residual property. Second, the basis for calculating the amount of compensation for land is not based on the actual price or market price but based on the determination of an appraiser and appointed by the land agency by assessing the object of land acquisition as stated in the provisions of Article 31 paragraph (1) and paragraph (2) of the Law Number 2 of 2012.

The provision of compensation for land acquisition for the public interest only emphasizes physical compensation, namely the loss of land, buildings and plants, moreover the value of the land released is not the same as the actual value or market value, this is contrary to the value of justice as stated by According to Aristotle, the judge is giving everyone something that is their due, and is not following corrective justice which requires adequate compensation for the injured party or in other words compensation repairs the loss, and does not otherwise make people worse or poorer than before. This is what happened in the provision of compensation for the implementation of land acquisition. It is not compensation that is their right but a proper and fair compensation based on the basic principle of balance. According to Sudjarwo Marsoem, namely "providing compensation for losses suffered by the old owner in an economic (financial) position that is at least the same as before the development project was held." Adi and Manoppo (2015).

This is what is meant by the provisions of Article 1 paragraph (2) and number (10), which are further described in Article 9 paragraph (1) and paragraph (2), in the implementation of land acquisition for the public interest. The balance between 
development and community interests is taken into account, and the parties are compensated appropriately and fairly. The contents of the article, which state about fair and suitable recompense both philosophically and legally, are unclear. If this is related to the balance between development and the community's interests, compensation must also be balanced. But this is not done by the government or agencies that require land rights for development.

On the other hand, based on the provisions of laws and regulations, starting from the revocation of land rights, land acquisition to land acquisition for the public interest, and in practice, the implementation seems to adhere to or be influenced by utilitarianism. It is evident from the legislation's provisions that the principle of benefit takes precedence over the idea of rights. Parties affected by the revocation of land rights, land acquisition, or land acquisition for the public interest are individuals or groups of people who are asked to sacrifice for the public good. Individual rights must be subordinate to the needs of society. So, it is not surprising if the compensated losses are only physical losses such as land, buildings, and plants, while non-physical losses are not considered. Likewise, the basis of calculations based not on actual prices or market prices shows the influence of utilitarianism which ignores individual rights and considers satisfaction in terms of material satisfaction which can be calculated mathematically.

According to John Rawls, an adequate theory of justice must be established with an agreement between the two parties. The jointly chosen standards of fairness are the outcome of a mutual agreement between all free, rational, and equal parties. The deal is always indicated as the foundation for deciding the site of the development plan, the type of compensation, and the amount of compensation in in-laws and regulations covering property acquisition for development in the public interest. Even in Law Number 2 of 2012 Article 2, it is stated that the basis for land acquisition for growth for the public interest is a trilogy of legal objectives theory which is described in the principle of justice, the focus of benefit and the direction of certainty. According to the provisions of this law, what is meant by the principle of justice is that in providing guarantees of proper compensation to parties who are entitled in the land acquisition process so that they get the opportunity to be able to carry out a better life. This includes the principle of expediency, namely the result of land acquisition that can provide broad benefits for the community, nation, and state. While the focus of certainty, namely providing legal assurance of the availability of land in the process of land acquisition for development and providing guarantees to parties entitled to receive appropriate compensation.

This Law Number 2 of 2012 does not provide further explanation regarding appropriate compensation based on the principles of justice, benefit, and certainty regarding the amount of compensation, including other problems related to land acquisition activities based on voluntarism and equality between the parties who own the land, buildings, plants, and other objects related to land, with parties who need land. Based on the purpose of land acquisition for the public interest, namely, to improve the welfare and prosperity of the nation, state and society while still guaranteeing the legal interests of the entitled parties following the provisions of Article 3 of Law Number 2 of 2012.

Suppose we pay attention to the understanding of justice, the principle of expediency and justice as mentioned above. In that case, some elements are at the core of that understanding. First, there must be no element of coercion to obtain mutual justice, and secondly, based on voluntarism and equality between the parties. This includes looking at the benefits received when the party gives compensation relinquishes his rights to the government or agency that needs the land. Not only the benefits used for development purposes can be enjoyed by all 
development users. Furthermore, in this case, the feasibility is appropriate for the user of the development but not suitable for the original party who controls the land rights.

The meaning of the laws and regulations regarding land acquisition for the public interest is stated in addition to the agreement, and justice is the basis for implementing compensation. Still, it is necessary to pay attention to if the parties or one of the parties are in a free, rational, and equal state, as stated by John Rawls. Inland acquisition for the public interest, it is difficult to say that the party who owns or controls the land is free and equal. The party that owns or manages the ground is not in an accessible position when the agreement is made. This position is also affected by the injustice in the deal.

Suppose there is no agreement because of injustice in the definition of the compensation after going through a legal process to the court, and the owner or landowner refuses. In that case, the compensation is deposited in court. Likewise, it is difficult to say that the party who owns the land or who controls the land is in an equal position or equal to the government because even though legally the parties' situation is similar, psychologically, they are in a weak place. So that what happens is that it is not an agreement for compensation that is obtained. Still, the holders of land rights are forced to consult or accept the decisions of the authorities/committees or are even forced to agree to get the compensation that harms the party holding the land rights.

Therefore, in the acquisition of land for the public interest, people may be asked to sacrifice for the sake of the public interest. Still, according to John Rawls, it cannot be justified that sacrifices are requested from less fortunate people (in this case, the party holding land rights). Indeed, there are always those who benefit more and those who benefit less. At the same time, the values of justice in land acquisition for the public interest, which are manifested in providing appropriate compensation to parties entitled to compensation, are closely related to the benefits felt by all Indonesian people, especially for parties entitled to compensation.

Justice in the provision of appropriate compensation for the implementation of land acquisition in Indonesia must be following the values of justice in Pancasila, among others, formulated in the principles of just and civilized humanity, which was first described in the Decree of the People's Consultative Assembly Number II/MPR/1978. then it was revoked by Decree of the People's Consultative Assembly Number XVIII/MPR/1988. In this formulation, fairness is described as dignity, equality, mutual love, appropriate attitude, not arbitrary, has human values, defends truth and justice and respects respect and cooperation with other nations. Meanwhile, the meaning of fairness in the principles of social justice for all Indonesian people is cooperation, a balance between rights and obligations, having social functions of property rights and living a simple life. Furthermore, referring to the formulation above, the perspective of justice according to the view of the Indonesian people is social justice. Based on this view, Indonesian people respect each other, care about the environment, and take care of their interests with the moral awareness of Pancasila, which gives recognition and respect to common interests in a balanced way, while respecting individual rights, especially in ownership rights that have been passed down from generation to generation in a balanced way for justice.

\section{CONCLUSIONS AND RECOMMENDATIONS}

The essence of what is needed in the provision of fair and proper compensation

is the essence of justice based on balanced justice values, namely justice that 
prioritizes the balance of interests and needs of each party, both holders of land rights, whose rights are needed for development for the public interest by The government or agency that needs land for this purpose is also based on the values of Indonesian socialism which are contained in just and civilized human values and social justice for all Indonesian people which are contained in Pancasila.

\section{ACKNOWLEDGEMENTS}

People who contributed to the work but do not fit criteria for authorship should be listed in the Acknowledgments, along with their contributions. It is advised that authors ensure that anyone named in the acknowledgments agrees to being so named. Funding sources that have supported the work should also be cited.

\section{REFERENCES}

A. Lubis, (2019) "Pelaksanaan Pembayaran Ganti Rugi Dalam Kegiatan Pengadaan Tanah Pembangunan Jalur Kereta Api Bandara Soekarno-Hatta Terhadap Bidang Tanah Yang Tidak Memiliki Alas Hak," DOKTRINA J. LAW, vol. 2, no. 1, pp. 1-12. Retrieved from https://doi.org/10.31289/doktrina.v2i1.2252

A. Shomad and P. Thalib, (2020) Pengantar Filsafat Hukum. Airlangga University Press.

B. Ismail, (1993) "Negara Hukum Demokrasi Toleransi." Jakarta : Intermedia.

B. Nasution, (2011) Negara Hukum dan Hak Asasi Manusia. Mandar Maju.

B. Tanya, Y. Simanjuntak, and M. Hage, (2010) Teori Hukum Strategi Tertib Manusia Lintas Ruang dan Generasi. Yogyakarta : Genta Publishing.

C. Wang and Y. Hu, (2020) "Malaysian and Mainland Chinese Social Network Community Users' Perceptions on Post-Mh370 Incident," Ultim. J. Ilmu Komun., vol. 12, no. 1 SE-Articles, May. Retrieved from https://doi.org/10.31937/ultimacomm.v12i1.1336

D. Anatami, (2017) Sekilas Tentang Hukum Jaminan, Hak Jaminan, Hak Tanggungan, dan Eksekusi Hak Tanggungan. Yogyakarta : CV. Budi Utama.

D. Utami, (2019) "Pelaksanaan ganti rugi dalam pengadaan tanah untuk kepentingan umum (proyek pembangunan middle ring road makassar)." Universitas Hasanuddin,.

E. Bodenheimer, (1974) Jurisprudence, The Philosophy and Method of The Law. Havard University Press, Cambridge, Massachusetts.

F. Fensi,(2018)"The Importance of Communication in Developing Modern Organization," Ultim. J. Ilmu Komun., vol. 9, no. 1 SE-Articles, Nov. Retrieved from https://doi.org/10.31937/ultimacomm.v9i1.875

J. Efendi and J. Ibrahim, (2018) Metode Penelitian Hukum: Normatif dan Empiris. Prenadamedia Group.

J. Goldie, (2018) "Pihak yang berhak mendapatkan ganti kerugian dalam pengadaan tanah bagi pembangunan untuk kepentingan umum di atas tanah paku alam," Jurist-Diction, vol. 1, no. 1, pp. 198-225. Retrieved from https://doi.org/10.20473/jd.v1i1.9742

J. Rawls, (1971) A theory of justice. The Belknap.

K. Benuf and M. Azhar, (2020) "Metodologi Penelitian Hukum sebagai Instrumen Mengurai Permasalahan Hukum Kontemporer," Gema Keadilan, vol. 7, no. 1, pp. 20-33. 
L. Arliman, (2018) "Peranan Metodologi Penelitian Hukum Di Dalam Perkembangan Ilmu Hukum Di Indonesia," Soumatera Law Rev., vol. 1, no. 1, pp. 112-132. Retrieved from https://doi.org/10.22216/soumlaw.v1i1.3346

M. Iskandar, (2019) Panduan Mengurus Sertifikat dan Penyelesaian Sengketa Tanah. Jakarta : Bhuana Ilmu Populer Kelompok Gramedia.

O. Yanto, (2020) Negara Hukum: Kepastian, Keadilan, dan Kemanfaatan Hukum Dalam Sistem Peradilan Pidana Indonesia. Bandung : Pustaka Reka Cipta.

P. Lestari, (2020) "Pengadaan Tanah untuk Pembangunan demi Kepentingan Umum di Indonesia Berdasarkan Pancasila," SIGn J. Huk., vol. 1, no. 2, pp. 71-86. Retrieved from https://doi.org/10.37276/sjh.v1i2.54

R. Chandra, (2020) "Penyelesaian sengketa sertifikat ganda hak atas tanah menurut PP No.24/1997 tentang Pendaftaran Tanah," Din. J. Ilm. Ilmu Huk., vol. 26, no. 3, pp. 358-371.

R. Subekti, (2016) "Kebijakan Pemberian Ganti Kerugian Dalam Pengadaan Tanah Bagi Pembangunan Untuk Kepentingan Umum," Yust. J. Huk., vol. 5, no. 2, pp. 376-394. Retrieved from https://doi.org/10.20961/yustisia.v5i2.8754

S. Marsoem, W. Adi, and P. G. Manoppo, (2015) Pedoman lengkap ganti untung pengadaan tanah: memetakan solusi strategis pengembangan infrastruktur di Indonesia: dilengkapi dengan berbagai peraturan penting tentang pertanahan. ReneBook

S. Rahardjo, (2000) Ilmu Hukum. Bandung : Citra Aditya Bakti.

S. Riyadi, D. Susilo, S. A. Sufa, and T. Dwi Putranto, (2019) "Digital marketing strategies to boost tourism economy: A case study of atlantis land Surabaya," Humanit. Soc. Sci. Rev, doi: 10.18510/hssr.2019.7553. Retrieved from https://doi.org/10.18510/hssr.2019.7553

S. Warjiyati, D. Susilo, and Suyanto, (2020)"Bear Up With Pandemic: Indonesian Tourism Discourse On Online News Media, Perspective On Law And Economic Growth," Psychol. Educ. J., vol. 57, no. 8, pp. 343-352.

Simanjuntak, (2015) Hukum Perdata Indonesia. Jakarta : Prenada Media Group.

Y. Sari, (2018) "Pengadaan Tanah Untuk Kepentingan Umum Ditinjau Dari Aspek Hak Asasi Manusia." Universitas Jember. 